\title{
CORRECTION
}

\section{Correction to: Potential risk assessment and spatial distribution of elemental concentrations in sediment}

\author{
T. F. Ediagbonya ${ }^{1}$ (1) O. T. Balogun ${ }^{1}$
}

Published online: 28 August 2020

(c) The Author(s) 2020

\section{Correction to: Applied Water Science (2020) 10:176 https://doi.org/10.1007/s13201-020-01260-w}

In the print published article, the footnote in Table 4 has been published incorrectly. The correct table with the footnote is given below.
The original article can be found online at https://doi.org/10.1007/ s13201-020-01260-w.

T. F. Ediagbonya

tf.ediagbonya@gmail.com; tf.ediagbonya@osustech.edu.ng

1 Department of Chemical Sciences, Olusegun Agagu

University of Science and Technology, Okitipupa,

Ondo State, Nigeria
Table 4 Correlation between physic-chemical parameters and elemental concentration

\begin{tabular}{lccccc}
\hline & $\mathrm{PH}$ & $\mathrm{EC}(\mathrm{us} / \mathrm{cm})$ & $\mathrm{Temp}\left({ }^{\circ} \mathrm{C}\right)$ & Chloride & Nitrate \\
\hline $\mathrm{Na}$ & 0.448 & -0.507 & $-.568^{*}$ & $-.560^{*}$ & $-.897 * *$ \\
$\mathrm{Mg}$ & $0.961^{* *}$ & -0.471 & $-.766^{* *}$ & 0.370 & $-.724^{* *}$ \\
$\mathrm{Al}$ & $0.907^{* *}$ & 0.125 & -0.246 & 0.250 & -0.319 \\
$\mathrm{Si}$ & $0.612^{*}$ & -0.118 & -0.376 & $0.842^{* *}$ & -0.075 \\
$\mathrm{P}$ & $0.848^{* *}$ & 0.220 & -0.164 & 0.425 & -0.160 \\
$\mathrm{Cl}$ & -0.078 & $-.872^{* *}$ & $-.659^{* *}$ & -0.023 & $-.522^{*}$ \\
$\mathrm{~K}$ & -0.222 & $-.744 * *$ & -0.506 & -0.465 & $-.607 *$ \\
$\mathrm{Ca}$ & $0.906^{* *}$ & 0.125 & -0.252 & 0.376 & -0.262 \\
$\mathrm{Ti}$ & -0.219 & 0.070 & 0.085 & -0.039 & 0.037 \\
$\mathrm{Cr}$ & $0.578^{*}$ & 0.259 & -0.057 & 0.193 & -0.161 \\
$\mathrm{Mn}$ & -0.235 & 0.314 & 0.290 & 0.194 & 0.345 \\
$\mathrm{Fe}$ & $0.580^{*}$ & -0.274 & -0.494 & $0.836^{* *}$ & -0.173 \\
$\mathrm{Cu}$ & $0.525^{*}$ & 0.419 & 0.127 & $0.691 * *$ & 0.333 \\
$\mathrm{Zn}$ & $0.844^{* *}$ & 0.071 & -0.299 & 0.250 & -0.389 \\
$\mathrm{Sr}$ & $0.791^{* *}$ & 0.116 & -0.229 & $0.691 * *$ & -0.052 \\
$\mathrm{Rb}$ & $-1.000^{* *}$ & -0.803 & 0.971 & -0.756 & -0.945 \\
$\mathrm{Zr}$ & -0.382 & 0.118 & 0.188 & 0.209 & 0.310 \\
$\mathrm{Ag}$ & 0.163 & $-.592 *$ & -0.501 & 0.062 & -0.374 \\
$\mathrm{Cd}$ & $0.648^{* *}$ & -0.299 & $-.522^{*}$ & $0.920^{* *}$ & -0.144 \\
$\mathrm{Sn}$ & $0.546^{*}$ & -0.095 & -0.239 & 0.005 & -0.290 \\
$\mathrm{~Pb}$ & $0.865^{* *}$ & -0.442 & $-.677 * *$ & 0.348 & $-.596^{*}$ \\
$\mathrm{Bi}$ & -0.991 & 0.189 & 0.082 & 0.803 & 0.945 \\
\hline$* \mathrm{C}$ & & & & &
\end{tabular}

*Correlation is significant at the 0.05 level (2-tailed)

***Correlation is significant at the 0.01 level (2-tailed) 
Open Access This article is licensed under a Creative Commons Attribution 4.0 International License, which permits use, sharing, adaptation, distribution and reproduction in any medium or format, as long as you give appropriate credit to the original author(s) and the source, provide a link to the Creative Commons licence, and indicate if changes were made. The images or other third party material in this article are included in the article's Creative Commons licence, unless indicated otherwise in a credit line to the material. If material is not included in the article's Creative Commons licence and your intended use is not permitted by statutory regulation or exceeds the permitted use, you will need to obtain permission directly from the copyright holder. To view a copy of this licence, visit http://creativecommons.org/licenses/by/4.0/.
Publisher's Note Springer Nature remains neutral with regard to jurisdictional claims in published maps and institutional affiliations. 